\title{
From a local observation to a European-wide phenomenon: Amphibian deformities at Serra da Estrela Natural Park, Portugal
}

\author{
Telma G. Laurentino' ${ }^{1}$, Miguel P. Pais ${ }^{2}$, Gonçalo M. Rosa ${ }^{3,4,5,6, *}$ \\ ${ }^{1}$ Computational Biology and Population Genomics Group, Centre for Ecology, Evolution and Environmen- \\ tal Changes (CE3C), Faculdade de Ciências da Universidade de Lisboa, Campo Grande, 1749-016 Lisboa, \\ Portugal. \\ ${ }^{2}$ MARE - Marine and Environmental Sciences Centre, Faculdade de Ciências, Universidade de Lisboa, \\ Campo Grande, 1749-016 Lisboa, Portugal. \\ ${ }^{3}$ Durrell Institute of Conservation and Ecology (DICE), School of Anthropology and Conservation, Univer- \\ sity of Kent, Canterbury, Kent, CT2 7NR, UK. \\ ${ }^{4}$ Institute of Zoology, Zoological Society of London, Regent's Park, NW1 4RY London, UK. \\ ${ }^{5}$ Centre for Ecology, Evolution and Environmental Changes (CE3C), Faculdade de Ciências da Universidade \\ de Lisboa, Campo Grande, 1749-016 Lisboa, Portugal. \\ ${ }^{6}$ Department of Biology, University of Nevada, Reno, NV 89557, USA.
}

*Correspondence: Phone: +44 7938699 431, +351 9162776 88, E-mail: goncalo.m.rosa@gmail.com

Received: 4 June 2015; returned for review: 9 September 2015; accepted: 2 December 2015.

In the last decades increasing records of morphological abnormalities in many amphibian populations have become subject of scientific interest. Once considered a mere curiosity, this worldwide phenomenon has been highlighted as a potential local conservation issue, for it appears to be yet another threat to amphibian diversity. Our study reports the first cases of amphibian deformities for North-Central Portugal, which are put in context with a review comprising European records since the $18^{\text {th }}$ century. Amphibian populations (Lissotriton boscai, Triturus marmoratus and Pelophylax perezi) were sampled for four sampling years at Serra da Estrela Natural Park. With approximately 1400 post-metamorphic individuals examined, we found 12 cases of deformity including anophtalmy, brachydactyly, ectrodactyly, ectomely, polydactyly and polyphalangy. Deformity prevalence varied between years and species, rarely exceeding $2 \%$. Our results are in accordance with European trends, since the majority of the recorded cases were found in limbs of urodeles. The presence of deformities in three different species points toward environmental causes, with predation as the most parsimonious explanation. Although not alarming, we reinforce the need for continuous monitoring of amphibian communities, from an interdisciplinary perspective, since even protected and pristine areas are not immune to new emerging threats that can act in synergy.

Key words: Lissotriton boscai; malformations; morphology; Pelophylax perezi; Triturus marmoratus.

De una observación local a un fenómeno paneuropeo: malformaciones de anfibios en el Parque Natural de la Serra da Estrela, Portugal. Durante las últimas décadas, el creciente número de registros de malformaciones morfológicas en anfibios ha suscitado el interés de la comunidad científica. Si bien al principio este fenómeno se consideraba apenas por mera curiosidad, el hecho de que se repita en todo el planeta lo ha convertido en un asunto de interés para la conservación a nivel local al postularse como una amenaza para la diversidad de anfibios. Nuestro estudio 
presenta los primeros casos de anfibios con malformaciones en la zona centro-norte de Portugal, y los pone en contexto con una revisión de los registros a nivel europeo desde el siglo XVIII. Durante cuatro años de trabajo, muestreamos poblaciones de diferentes especies de anfibios (Lissotriton boscai, Triturus marmoratus y Pelophylax perezi) en el Parque Natural de la Serra da Estrela. Tras examinar aproximadamente 1400 individuos pos-metamórficos, hallamos 12 casos de malformaciones incluyendo anoftalmia, braquidactilia, ectrodactilia, ectomelia, polidactilia y polifalangia. Las prevalencias de malformaciones variaron entre años, aunque raramente superaron el $2 \%$. Nuestros resultados coinciden con las tendencias a nivel europeo, apareciendo la mayoría de los casos en extremidades de urodelos. La presencia de malformaciones en tres especies distintas apunta a los factores ambientales, y en particular a la depredación, como la explicación más factible. Aunque no parece un problema alarmante, señalamos la necesidad de realizar seguimientos continuados en las comunidades de anfibios desde una perspectiva multidisciplinar, dado que incluso aquellas áreas prístinas y protegidas podrían no ser inmunes a nuevas amenazas que pueden actuar de forma sinérgica.

Key words: Lissotriton boscai; malformaciones; morfología; Pelophylax perezi; Triturus marmoratus.

Amphibians are particularly sensitive to perturbations of the surrounding ecosystem, being considered by some authors as bio-indicators of environmental health (Tejedo, 2003; García-Muñoz et al., 2010). In fact, this group of animals currently faces global declines and range reductions worldwide (STUART et al., 2004; Hof et al., 2011). In addition, reports of populations with severe morphological abnormalities increased, reaching an unprecedented rate (GARcíA-Muñoz et al., 2010). Literature from the last decade is focused on population level analyses and descriptions of mass occurrences of deformities (e.g. Hoppe, 2005). However, the most common types of records, described since the $18^{\text {th }}$ century, are those of isolated cases of morphological abnormalities in adult amphibians (Ouellet, 2000; Henle et al., 2012). Despite the amount of available data, field sampling and intensive investigation of the problem are not homogeneously distributed across geographic range, leading to bias and gaps in data records (ReEves et al., 2013). Although abnormalities resulting from both genetic and environmental factors are expected in any amphibian population, the proportion of this natural emergence is usually about $2 \%$ (ReEves et al., 2013). Higher deformity rates have been associated with noxious environmental modifications, which also led to massive mortality of eggs, larvae, and adults (Flyaks \& Borkin, 2004; HAyden et al., 2015), evidence that is causing debate over the possibility of a rising conservation problem (BurKHART et al., 2000; BLAUsteIN \& Johnson, 2003). While no single cause can explain all deformities, numerous factors have been proposed as explanations for these phenomena, with environmental stressors being more frequently mentioned than genetic causes.

The causal factors behind morphological deformities often remain unclear (Johnson et al., 1999; Blaustein \& Johnson, 2003), since synergistic interactions between two (Kiesecker, 2002) or multiple factors (Reeves et al., 2010) may occur. The genetics of vertebrate limb abnormalities is relatively well known and a considerable 
number of genes have been linked to congenital limb deformities (e.g. ManouvrierHanu et al., 1999; Hill \& Lettice, 2013). Notwithstanding, natural mutation rates or inbreeding do not seem plausible explanations when high frequencies of abnormality are observed for multiple species, and across broad geographic range (Blaustein \& Johnson, 2003; Williams et al., 2008). Instead, biotic interactions and environmental factors are often highlighted as the cause. Predation can give rise to deformities due to problems in the regeneration process (epimorphosis) following trauma (BALlengée \& SEssions, 2009). Equally, infection by teratogenic viruses, fungi and other parasites have been associated with the emergence of deformities. Special attention has been paid to the trematode Ribeiroia ondatrae, which has been considered a cause for limb deformities, particularly supernumerary limbs, in North America (e.g. SEssions \& Ruth, 1990; JoHnson et al., 1999; LANNoo, 2009). Even if we consider that the increasing number of reports may not be linked to a higher frequency of malformation occurrences, an increment in the stressors seems to be occurring in nature. Ubiquitous stressors like UV-B radiation, ground-level ozone, acid precipitation and extreme temperatures, as well as products of anthropogenic activities such as chemical contaminants and radioactive mineral deposits, and even proximity to roads (ReEves et al., 2008) are considered to play a role in the appearance of morphological abnormalities.

The most frequently reported amphibian deformities affect post-metamorphic limbs, and appear to fall into two broad categories: absent limbs or limb portions (ectomely or ectrodactyly), and supernumerary limbs / digits (polymely or polydactyly) (Ouellet, 2000). Several types of malformations have been described for various species of Iberian amphibians, for both Anura (e.g. Cisternas, 1865; Galán, 2011) and Urodela (HÉron-Royer, 1884; FERnÁndez-Álvarez et al., 2011). However, the great majority of these observations have been episodic, single species cases, and purely descriptive, with no analysis of possible causative factors, and no concerted effort to evaluate the effects of deformities on amphibians.

The present work reports new cases of post-metamorphic deformities, affecting both urodeles and anurans from northcentral Portugal, which are put in context with a review of other European records of amphibian abnormalities. Additionally, our records expand the geographic range of observed deformities in amphibians, and contribute to the understanding of possible causes of this phenomenon.

\section{Materials and Methods}

\section{Study sites}

Serra da Estrela is the highest mountain in Portugal's mainland territory, with a maximum altitude of $1993 \mathrm{~m}$. Integrated in the Iberian Central Range, it is located in the eastern part of north-central Portugal (Daveau, 1971; Mora et al., 2001), and comprises the largest protected area in Portugal: Serra da Estrela Natural Park (PNSE).

The cases here reported took place in two concrete tanks originally created for forestry purposes, filled with spring water in constant flow, and a natural pond situated within the borders of PNSE (Fig. 1). 

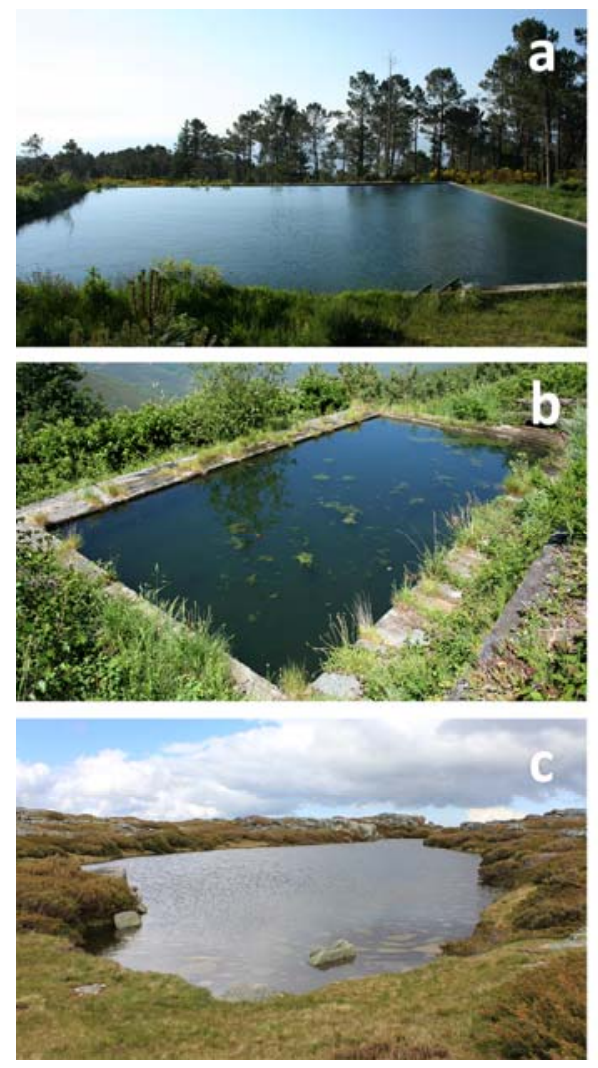

Figure 1: Sites at Serra da Estrela Natural Park (Portugal), where we report cases of abnormalities in amphibian species, Lissotriton boscai, Triturus marmoratus and Pelophylax perezi between 2011 and 2014. (a) Tanque de Folgosinho. (b) Tanque dos Serviços Florestais de Sazes. (c) Salgadeiras pond. Photos (a) and (b) by M. Madeira, photo (c) by G.M. Rosa.

Both tanks, one situated near the village of Folgosinho (Gouveia) (40²9'37.09'N, $7^{\circ}$ 31'47.61'W, 1079 m; Fig. 1a) and the other in Sazes da Beira (Seia) $\left(40^{\circ} 20^{\prime} 39.7^{\prime \prime} \mathrm{N}, 7^{\circ}\right.$ 42'52.63'”W, 985 m; Fig. 1b) were surveyed two to three times per year between 2011 and 2014. The pond located in Salgadeiras $\left(40^{\circ} 20^{\prime} 18.80^{\prime \prime} \mathrm{N}, 7^{\circ} 36^{\prime} 55.21^{\prime \prime} \mathrm{W}, 1850\right.$ m; Fig. 1c) was surveyed in 2010 and 2014.

\section{Survey}

Sampling was performed during an ongoing amphibian-monitoring project

\section{Serra da Estrela \\ Natural Park}

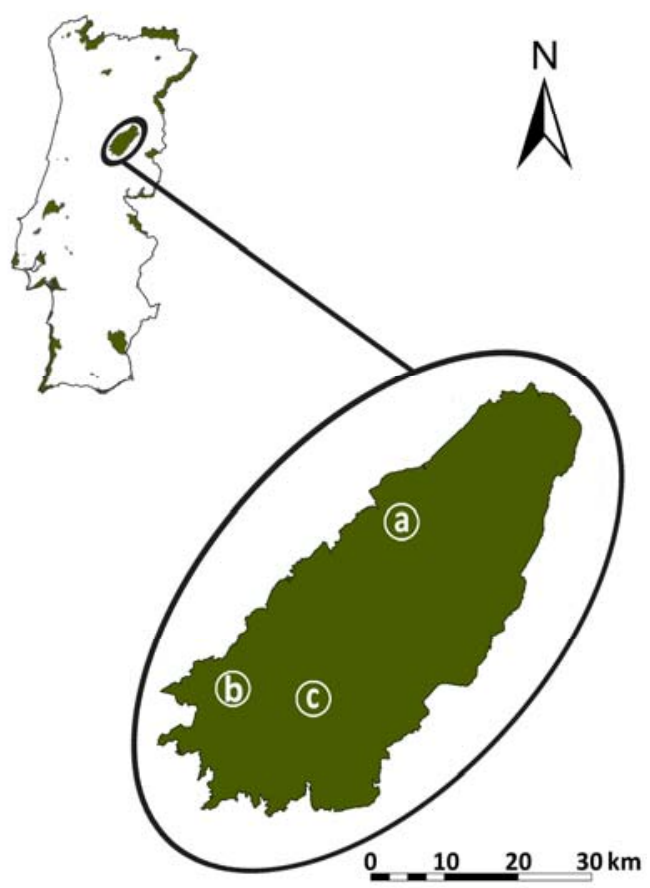

focused on emerging diseases (RosA et al., 2013) covering three different seasons (spring, summer and autumn). On each occasion, sites were sampled by two researchers (using hand nets) for a total of two hours. All specimens were returned to the habitat after sampling.

Throughout the four sampling years a total of 100 post-metamorphic (p-m) and 68 larvae of Triturus marmoratus, and 811 p-m and 255 larvae of Lissotriton boscai were identified at Folgosinho tank. At the Sazes tank, a total of 177 p-m and 321 lar- 
AMPHIBIAN DEFORMITIES IN PORTUGAL

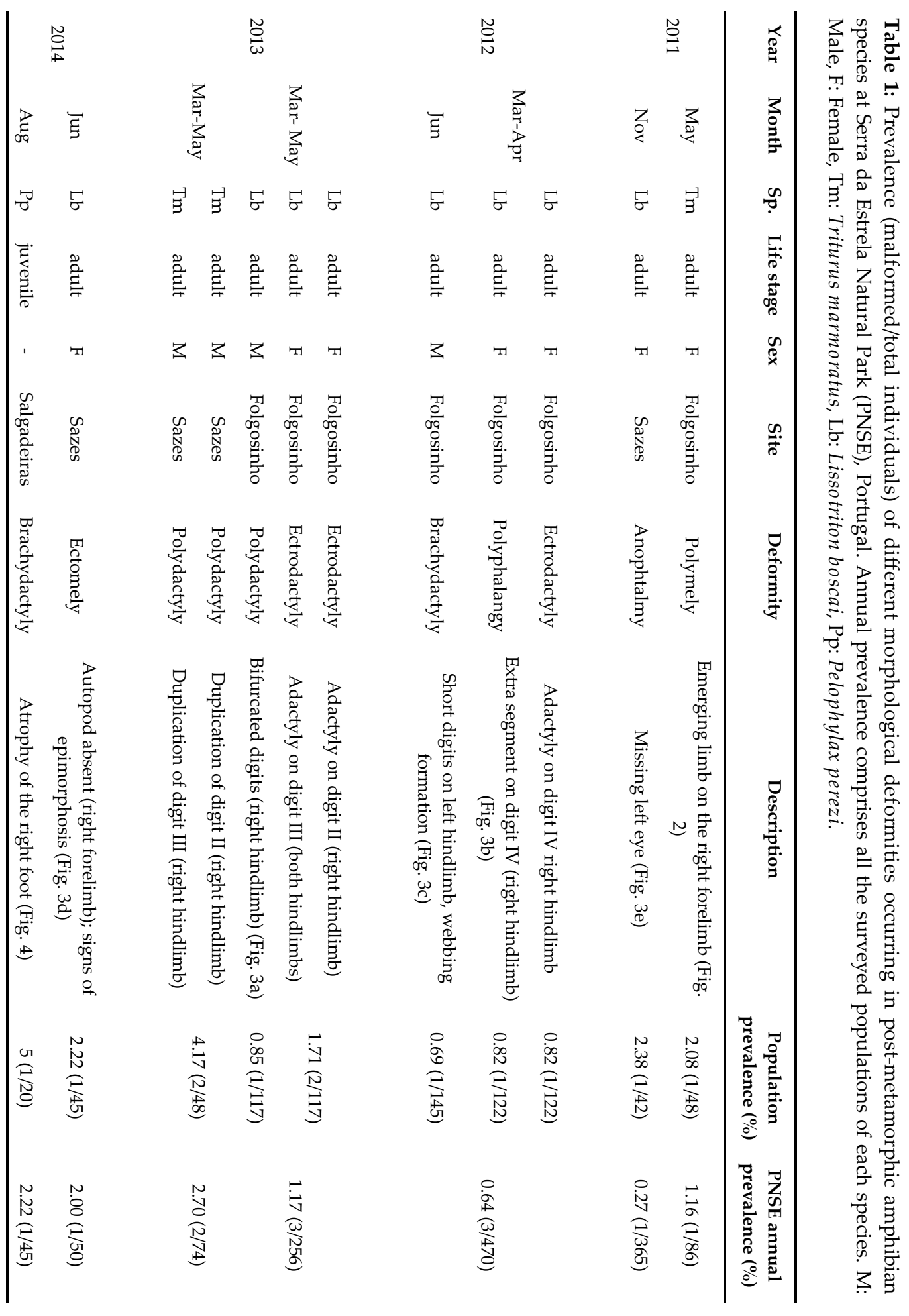


vae of T. marmoratus, and $304 \mathrm{p}-\mathrm{m}$ and 577 larvae of L. boscai were found. Regarding Salgadeiras pond, 40 p-m individuals of Pelophylax perezi were sampled throughout the two years. No animals were sacrificed in order to obtain the data presented in this paper. Classification of the deformity type followed the nomenclature described in RotнsснiLd et al. (2012).

The baseline (under which the prevalence is considered normal and of little concern) adopted for the interpretation of the prevalence of deformity found in the present analysis was $2 \%$, as established by ReEves et al. (2013) in a recent study comprising a dataset of almost 50000 anuran specimens.

\section{Hydrochemical analysis}

Recently, livestock pressure is low in the study area and water sources do not show any signs of eutrophication, being continuously supplied with spring water. Nevertheless, in order to exclude possible contamination by remnant pesticides or fertilizers, water samples were collected in 2012 to assess water parameters. $\mathrm{pH}$ was measured in the field with a portable kit (precision 0.1) and the concentrations of nitrites, nitrates and ammonium was de- termined with spectrophotometry, using the methods described in Grasshoff (1976). Suspended particulate matter was determined by filtering water through preweighed GF / C Whatman filters, which were subsequently dried at $80^{\circ} \mathrm{C}$ for 24 hours and reweighed. Heavy metal concentrations were determined through Flame Atomic Absorption Spectrometry (Duarte \& Caçador, 2012).

\section{European literature review}

In order to better comprehend the context and impact of the herein described and investigated malformations, we reviewed the available literature documenting any amphibian morphological deformities in European territory from 1816 to 2014. Records from Russia have been excluded from the analyses due to imprecise locality of the reports. Nonetheless, see Borkin \& Pikulik (1986) and Lada (1999) for polymely and polydactyly records in natural populations of Anura, in Russian Eurasian territory.

We considered one record the report of a certain malformation at a certain time per species, per site: e.g. 1) two different manuscripts mentioning a tail deformity in a salamander population in the same
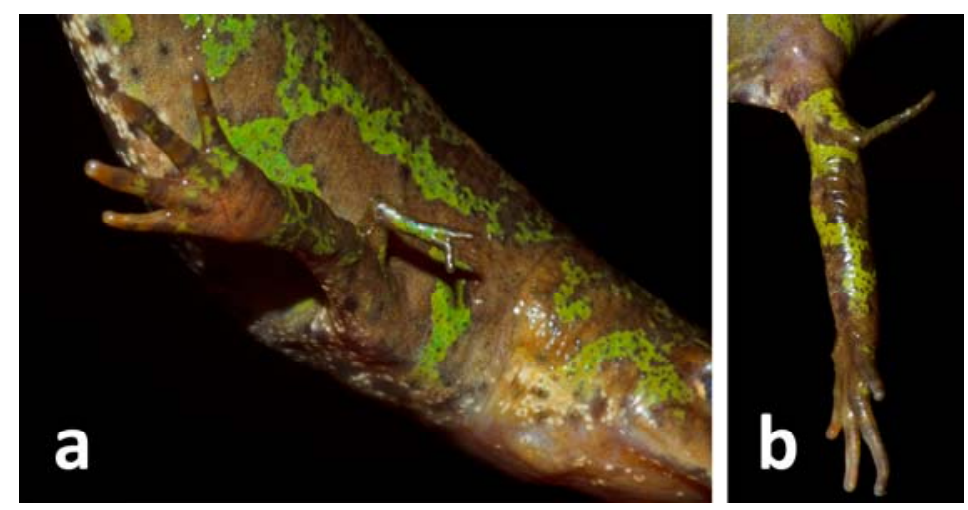

Figure 2: Polymely in adult Triturus marmoratus from Serra da Estrela NP presenting an extra limb emerging from its right forelimb with reduced limb segments (May 2011). (a) and (b) provide different angles of the emerging limb. 

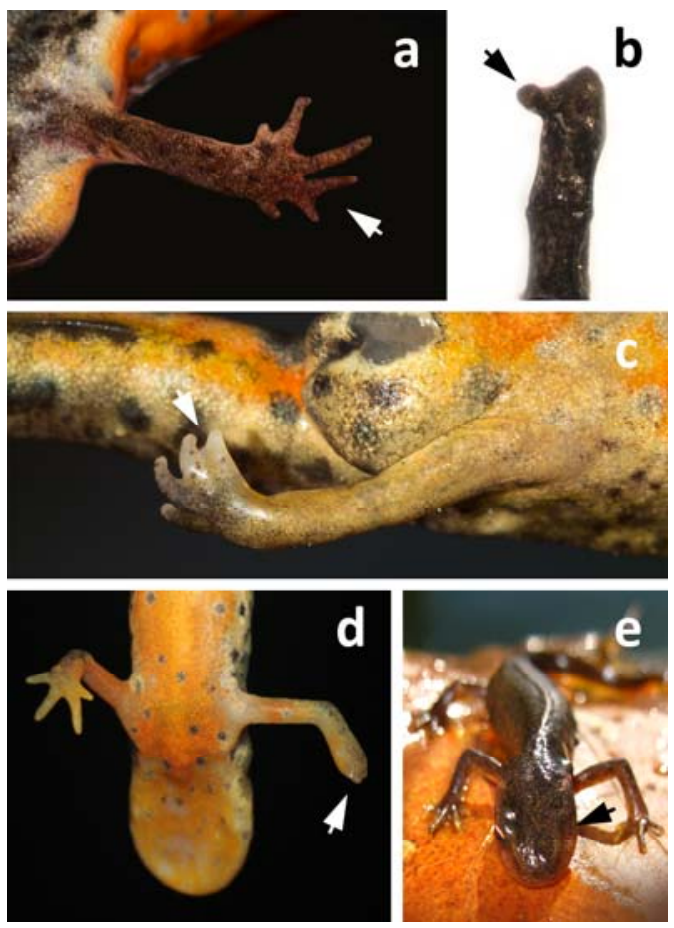

Figure 3: Three types of abnormalities in adult Lissotriton boscai at Serra da Estrela NP. (a) Polydactyly (with bifurcation) in toe IV of right hind-limb (May 2013). Polyphalangy (partial duplication) in toe IV (dehydrated toe-clip) (March 2012). (c) Brachydactyly in an adult individual with webbing development (June 2012). (d) Ectomely with blastema in right hind-limb probably resulting from injury or predation attempt (June 2014). (e) Eye abnormality in a female missing the left eye (Anophthalmia) (November 2011). Arrows point to the malformations.

year would count as one record; 2) one manuscript reporting on two different malformations (polymely and ectrodactyly) in a single population would count as two records. Additionally, in our analyses, reports from captive specimens or resulting from experimental work were not considered. All the reviewed literature is listed in the Supplementary Material (Section S1).

\section{Results}

\section{Amphibian deformities in north-central Portugal}

Between May 2011 and June 2014 we recorded 12 cases of deformities out of almost 1400 post-metamorphic individuals examined across three different species of amphibians from Serra da Estrela. Despite the fact that no larvae were found with obvious deformities, detectability of limb and digit deformities is rare in larval stages, due to reduced limb sizes. Additionally, due to the importance of returning the individuals unharmed to their locations, with minimal interference, our analysis was restricted to external examination of each individual.

Limb and digit abnormalities were the most often observed (see Table 1 for more details), where five of the cases corresponded to supernumerary limbs or digits: the first was a female $T$. marmoratus found in 2011 with a third arm emerging from the right forelimb, fused at the humerus (Fig. 2). The supernumerary forelimb is overall shrunken in size, appearing to be composed of humerus and radioulna, with two fingers at the distal end. Later on (May 2013), two individuals of this same species were caught presenting digit duplication in the hindlimbs. The same deformity had been already recorded in Folgosinho, on a L. boscai male captured in 2012 (Fig. 3a). A case of polyphalangy was observed in a female $L$. boscai with an extra segment, orthogonally oriented in relation to the normal digit, emerging at the boundary between distal 
and intermediate phalanx (Fig. 3b).

Absence and atrophy or shortness of digits was also observed in Serra da Estrela. In 2012-2013 three adult individuals of L. boscai showed digit deformities, specifically adactyly: digits were missing on hindlimbs, without any trace of scarring tissue, visible blastema or epidermal pigmentation alteration. None of the cases presented visible signs of epimorphosis and there was not abnormal spacing between the remaining digits, unlike adactyly described in other studies, where the missing digits result in surplus space (e.g. see Fig. 1(a) in Williams et al., 2008). Another individual of L. boscai, sampled in June 2012, presented abnormally short digits (brachydactyly). The deformity began at the zeugopod with increasing severity at the autopod (Fig. 3c). Inter-digital webbing could be observed, suggesting an ongoing process of epimorphosis that could originate this phenotype. An additional case of brachydactyly was reported in a postmetamorphic P. perezi captured in 2014 (Fig. 4): Calcanium and Talus seemed to be present and digits individualized, while the others were united by abnormal webbing, being shorter than usual (Fig. 4b).
Lastly, two other L. boscai were found with rarer conditions: one in Sazes presenting ectomely, where the autopod was absent but signs of epimorphosis were visible (specifically the regeneration blastema), suggesting a deformity caused by trauma (Fig. 3d); and another with a cranio -facial deformity (Fig. 3e). The latter individual exhibited unilateral anophthalmia, missing the left eye; the eye-socket was covered with skin, with no indication of scarring or pigmentation abnormalities. Overall, notwithstanding the described phenotypic abnormalities, the animals did not show abnormal behaviour when in water or when handled by the experimenters.

\section{Deformities prevalence for amphibians at PNSE}

Deformity prevalence varied over the years. Prevalence at the individual breeding sites ranged from $0.69 \%$ to $2.38 \%$ for $L$. boscai, and from $2.08 \%$ to $4.17 \%$ for T. marmoratus (Table 1). Highest prevalence was detected in 2013 in Sazes for T. marmoratus with $4.17 \%$ polydactyly (which represents two individuals out of 48 sampled), and in the following year in $P$. perezi with
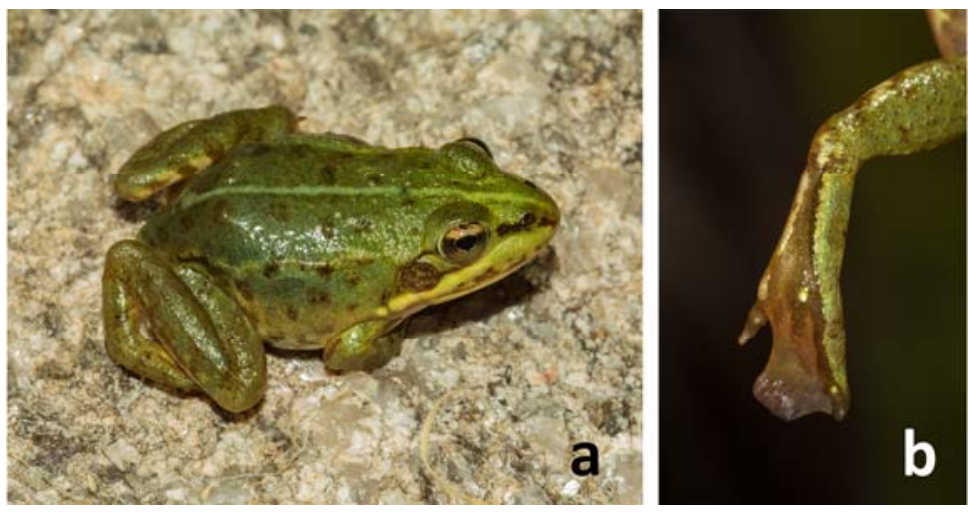

Figure 4: Brachydactyly in juvenile Pelophylax perezi from Serra da Estrela NP with webbing formation in its right hind-limb (August 2014). (a) Dorsal view of the malformed individual. (b) Close up of right foot showing the details of abnormal webbing formation. 
Table 2: Water quality standards for some compounds for fish-breeding ponds in the former USSR (Kosyreva, 1971) and for aquaculture in USA (Lawson, 1995). Comparative data from a site at the Dnepropetrovsk District (eastern Ukraine) where mass abnormalities were attributed to high levels of heavy metals (FLYAKs \& BorKIN, 2004), in contrast to the levels obtained for Serra da Estrela Natural Park (PNSE) are shown. LOD: limit of detection of the method. Values in mg / 1 except for $\mathrm{pH}$.

\begin{tabular}{cccccc}
\hline Compound & \multicolumn{2}{c}{ Standards } & \multicolumn{3}{c}{ Case studies } \\
& USSR & USA & $\begin{array}{c}\text { Dnepropetrovsk } \\
\text { District (1995) }\end{array}$ & $\begin{array}{c}\text { Folgosinho, } \\
\text { PNSE (2012) }\end{array}$ & $\begin{array}{c}\text { Sazes, } \\
\text { PNSE (2012) }\end{array}$ \\
\hline Ammonium $\left(\mathrm{NH}_{4}{ }^{+}\right)$ & up to $0.50-1.50$ & - & 2.50 & 0.32 & - \\
Nitrite $\left(\mathrm{NO}_{2}{ }^{-}\right)$ & up to $0.01-0.10$ & 0.1 (soft water) & 0.025 & $<1$ & $<1$ \\
Nitrate $\left(\mathrm{NO}_{3}{ }^{-}\right)$ & $1.0-2.0$ & $0.00-0.30$ & 1.470 & 0.5 & 0.5 \\
pH & $6.5-8.0$ & $6.5-8.0$ & $5.0-6.8$ & 6.8 & 6.3 \\
Hardness & - & $10-400$ & - & 216.7 & 200 \\
Zinc $(\mathrm{Zn})$ & 0.01 & $<0.005$ & $4.66 \pm 0.050$ & $<$ LOD & $<$ LOD \\
Manganese $(\mathrm{Mn})$ & - & $<0.01$ & $0.39 \pm 0.030$ & $<$ LOD & $<$ LOD \\
Copper $(\mathrm{Cu})$ & 0.01 & $0.03^{*}$ & $0.15 \pm 0.050$ & $<$ LOD & $<$ LOD \\
Lead $(\mathrm{Pb})$ & 0.10 & $<0.02$ & $0.06 \pm 0.004$ & $<$ LOD & $<$ LOD \\
Nickel $(\mathrm{Ni})$ & 0.01 & $<0.1$ & $0.19 \pm 0.060$ & $<$ LOD & $<$ LOD \\
Cadmium $(\mathrm{Cd})$ & 0.005 & $0.005^{*}$ & $0.02 \pm 0.005$ & $<$ LOD & $<$ LOD \\
\hline
\end{tabular}

${ }^{*}$ At alkalinity levels $>100 \mathrm{mg} / \mathrm{l}$.

$5 \%$ brachydactyly observed in that sampling event in Salgadeiras (single individual in 20 analysed). Although with relatively low frequency of occurrence, the most common malformations recorded across time, space and species were the supernumerary deformities. Anophtalmy was the least commonly recorded malformation and the only one not affecting limbs and / or digits. Overall, rates of deformity met the estimated $2 \%$ baseline (ReEves et al., 2013), with those two previously mentioned exceptions. Nevertheless, we must take into account the small sample sizes, particularly the sampled population of P. perezi in summer 2014 (Table 1). However, when looking at the annual prevalence we see a drop in the frequency and an approximation to the expected values.

\section{Hydrochemical analysis}

Hydrochemical analysis of Folgosinho and Sazes sites did not provide any unusual values, falling within water quality standards (Table 2). Our results are similar to standard values of natural pond water quality, being different from values correlated with deformity outbreak scenarios. Moreover, there is no indication of $\mathrm{pH}$ alteration or chemical contamination. Levels of nitrates and ammonium, which can result from fertilizer usage, are regular. Contamination by heavy metals is also 
negligible, since all values are below the detection limit of the method (Table 2).

\section{European literature review}

A review of the literature shows that over 20 European species of anurans and 16 species of urodeles with morphological abnormalities have been documented, since the $18^{\text {th }}$ century. The majority of reports, especially for Iberian Peninsula, are of anecdotal nature and comprise individual specimens, with no further investigation of population impact, and environmental or developmental causes of malformation. Within Europe, the number of reports is unevenly distributed regarding both countries and species, reflecting the global geographical distribution of records (Ouellet, 2000; Lannoo, 2009; Fig. 5; Section S1).

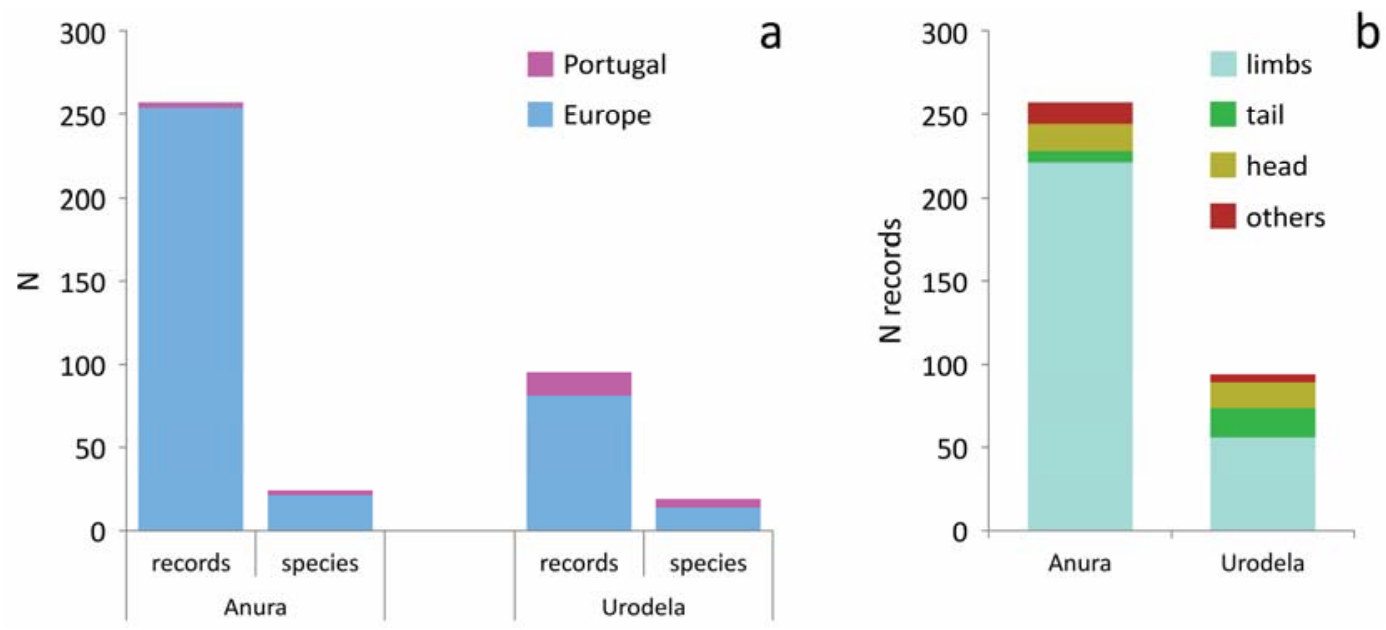

In Portugal, more urodeles than anurans are reported bearing deformities. Portuguese reports represent $1.2 \%$ and $16.9 \%$ of Anura and Urodela European reports, respectively (Fig. 5).

Regarding the affected body parts, limb abnormalities are by far the most commonly reported and seem to primarily involve the hindlimbs, whether in the form of missing, extra, or malformed limbs (Hebard \& Brunson, 1963; Ouellet et al., 1997; Hoppe, 2005).

\section{Discussion}

Deformity prevalence is influenced by site and species ecological dynamics

Morphological abnormality naturally arises in all organisms, but the definition of a prevalence baseline for amphibians

a

Figure 5: Records of amphibian deformities across Europe reported in literature between 1864 and 2014. (a) deformity records and number of species affected by Order, highlighting the records from Portugal within Europe. (b) Body parts affected by Order; limbs also include toes and fingers; tail in Anura refers exclusively to the larval stage deformities; head also includes mouth and eye deformities; others include body axes, vertebral and spine deformities. Records from Russia have been excluded from the bar charts (see Borkin \& PikUlik (1986) and LAdA (1999) for polymely and polydactyly records in natural populations of Anura in Russian Eurasian territory). 
has been subject of much discussion due to variation caused by geographic region, species under study, type of abnormalities being considered, and method of detection (Johnson et al., 2010; LUNDe \& JoHnson 2012).

When studying Portuguese populations of both T. marmoratus and L. boscai, M. H. Caetano found no abnormalities on individuals from central and northern Portugal. Contrastingly, $7.4 \%$ of the studied specimens from the south presented limb deformities, including polydactyly, polymely and adactyly (CAETANO, 1988). However, no further investigation was conducted and no cause was associated with the elevated deformity prevalence described. We found deformities of similar nature as those reported, more than 20 years after, but this time for the northcentral part of the country and with lower rates. Geographically located between previously surveyed areas in continental Portugal, Serra da Estrela is thus an essential piece of the puzzle given the high prevalence found in the south and the absence of deformity records in the north, suggesting a north-south gradient of decreasing prevalence.

\section{Possible causes and consequences for am- phibian conservation}

The variety of causes, either natural or anthropogenic, and the potential interaction of stressors preceding morphological deformities in amphibians is vast (Lannoo, 2009; Lunde \& Johnson, 2012). Habitats where similar abnormalities are found may be affected by unrelated causes and, conversely, multiple interacting stressors may be operating within a single wetland (Johnson et al., 2010; Reeves et al., 2011; Hayden et al., 2015). Consequently, finding the origin of amphibian malformations is a complex task (BLAustein \& JoHnson, 2003; Johnson \& Bowerman, 2010).

In the absence of a clear cause-effect relationship, some conclusions can be drawn by ruling out implausible causes based on available data. Environmental stressors, such as aquatic eutrophication, can promote pathogenic infection in amphibians (Johnson et al., 2007), enhancing the chances of arising deformities caused by parasites. However, none of the sampled study sites ever showed signs of eutrophication. Another possible cause are genetic mechanisms, but then it is expected that individuals from the same population exhibit similar malformations (LanNoo, 2009), which was not the case in the accessed study areas. The hypothesis of parasites being the cause of the found abnormalities is improbable, especially since the deformity prevalence found is low, comparatively to what is expected when parasites such as the trematode $R i$ beiroia ondatrae are present (LANNoo, 2008). Additionally, aquatic snails from genera Helisoma, Planorbella or Biomphalaria (JoHnson et al., 2004; JoHnson \& McKenzie, 2008) are necessary vectors for this trematode parasite, and even though genus Planorbella is described for Portugal (Simões, 2005), it has not been reported to the area of Serra da Estrela (Albuquerque de MATos et al., 2014).

Xenobiotic substances such as fish excrement and lathyrogens (LanNoo, 2008, 2009) have also been pointed as causative factors of deformity. Notwithstanding, no 
fish species are present in any of the habitats sampled and Lathyrus odoratus, which naturally produces lathyrogens, is not included in the flora inventory of Serra da Estrela Natural Park (TAlavera et al., 2001; JANSEN, 2002). Outbreaks of amphibian deformity have also been associated with agricultural soils, where chemical contamination frequently occurs due to heavily used fertilisers and pesticides (e.g. Bacon et al., 2006, GURUSHANKAra et al. 2007, Reeves et al., 2008). However, this seems an improbable scenario for the herein reported deformities since Folgosinho tank showed no signs of chemical or heavy metal contamination.

Of all possible causes, trauma is usually a main suspect in deformity scenarios (Ballengée \& Sessions, 2009; Bowerman et al., 2010), mainly resulting from failed predation attempts (LANNoo, 2009). In urodeles, after an injury event, regeneration of the lost tissue requires coordinate reactivation of developmental and pattern signalling pathways, and recent trauma may produce evidence of epimorphosis or scarring. These signs were absent in all individuals, except for the one presenting ectomely, which exhibited a typical blastema, indicating ongoing regeneration (Whited \& TABIN, 2009). However, developmental responses of the injured or amputated limb can range from no regeneration to hyper-regeneration, with intermediate conditions represented by various types of limb deformities (BALlengéE \& SEssions, 2009). This abnormal regeneration process could actually justify most of the deformities we found in Urodela specimens here described. This is not an outlying hypothesis since selective predation by dragonfly nymphs and other aquatic predators has been associated with the most common kinds of limb deformities found in natural populations of anurans (Ballengée \& Sessions, 2009). Moreover, Odonata nymphs of various species, which have been indicated as predictors of skeletal abnormality frequency (BALLENGÉ \& Sessions, 2009; Bowerman et al., 2010; ReEves et al., 2010), and diving beetles (Dysticidae), are abundant in Serra da Estrela, particularly in the surveyed sites (RosA et al., 2012). Interspecific predation on adult $L$. boscai by T. marmoratus has also been observed at Folgosinho (BAPTISTA et al., 2015), reinforcing the idea of predation as a key stressor in these habitats. But even with predators appearing as the most plausible cause, multiple factors are almost certainly responsible for the amphibian abnormalities documented since the early 1990s (JoHnson et al., 2010), and by studying causative factors in isolation we may be missing essential cues regarding the environmental conditions that result in amphibian deformity.

Climate change has been pointed as one of the major global causes of amphibian population declines (Hof et al., 2011), being able to mediate the impact of other factors such as predation rate. Temperature has been shown to influence abundance of predatory invertebrates, leading to increased predatory activity (ANDERSON et al., 2001; ReEves et al., 2010; Hayden et al., 2015). It has also been linked to the occurrence of chytridiomycosis outbreaks in Spain (Bosch et al., 2007), which is alarming, since chytrid fungi have been detected at Serra da Estrela mediating a significant decline on the population of midwife 
toads, Alytes obstetricans (Rosa et al., 2013). Furthermore, exposure to UV-B may also increase susceptibility to predation and to infections (KIESECKER et al., 2001; Romansic et al., 2009), leading to higher prevalence of malformation and mortality, especially during embryonic development (Blaustein et al., 2003). Although predation seems the most plausible cause for the new records we present, dragonfly nymphs and other aquatic predators are ubiquitous in wetlands inhabited by amphibians worldwide.

The data presented show that the number of reported deformities should be carefully monitored, and should not be disregarded as simply an increase in the number of reports alone. In fact, predators, emerging infectious diseases and climate change, which could have a lesser impact individually, can cause severe problems when acting synergistically (BLAUsteIn et al., 2003; LANNOo et al., 2003; ReEves et al., 2010).

\section{Literature review: context for new Portu- guese records}

The review of the available literature allowed us to validate that the herein described are the first records of malformation in the studied amphibian populations. The majority of Iberian reports are focused on isolated specimens, with no recurrent sampling of the study sites, being unclear how many historical records were part of a population phenomenon, which hinders the establishment of an accurate baseline. Once again, the need for deeper analysis of this phenomenon from a population perspective is evident, with environmental assessment of possible causes.

The present review is in agreement with the global hypothesis of deformity being naturally more frequent in anurans (LANNOO, 2009). However, contrary to the general European trend, more urodeles than anurans are reported bearing deformity for Portugal. Nonetheless, this result can be biased due to more intensive demographic studies regarding urodeles performed in this country.

By looking at the newly reported cases in Serra da Estrela in a European context, it is evident that they fit the tendency for higher frequency of limb malformations, particularly affecting hindlimbs. In fact, excluding a single case of head deformity, every individual herein reported presented limb deformity, among which $81.8 \%$ affected hindlimbs. BALlengé \& Sessions (2009) attributed this fact was, at least partially, to the exposure of hindlimbs to predation. Regarding head deformities, the fact that they appear rare when compared to limb deformities can probably be related to a high mortality incidence when head or spinal cord are affected by malformation (LANNOO, 2008).

\section{Final considerations}

Deformities might impair mobility, decrease food intake, increase susceptibility to predators and parasites, and may eventually impact entire populations, leading to high levels of mortality (BLAUstein \& JoHnson, 2003), with deformed amphibians only rarely surviving to adulthood (Johnson et al., 2001). Despite of that, wildlife malformations only become a serious conservation issue if mediated by human actions, directly or indirectly. 
To date, no physical abnormality crisis has been reported in Europe. However, several European species face alarming declining rates and range reductions. In the Iberian Peninsula, where a great fraction of the herpetofauna is endemic, there is a considerable lack of studies regarding this phenomenon.

Despite being treated multiple times in the recent literature as a global alarming phenomenon, the increase in the number of malformation records most likely results from increasing interest and more extensive population surveys. Furthermore, both the methodology to establish baselines and the study of causative factors behind the observed patterns lack uniformity across the literature, thus leading to bias in the perception of local phenomena. Nevertheless, we consider that even isolated records should not be ignored, since these may add valuable information to the geographic range of amphibian abnormalities, drawing attention to potential hotspots of deformity that will otherwise remain unnoticed.

\section{Acknowledgement}

We thank José Conde (CISE) and Ricardo Brandão (CERVAS) for logistical support; Bernardo Duarte (MARE), Frank Pasmans and Mark Blooi (Ghent University) for helping with hydrochemical analysis; Madalena Madeira for all the help in the field. Research permits were provided by the Instituto da Conservação da Natureza e das Florestas (yearly renewed 19/2012/ CAPT). G. M. Rosa holds a doctoral scholarship (SFRH/BD/69194/2010) and M. P. Pais a postdoctoral scholarship (SFRH/ BPD/94638/2013), both from Fundação pa- ra a Ciência e a Tecnologia (FCT).

\section{REFERENCES}

Albuquerque de Matos, R. M. (2014). Atlas dos Caracóis Terrestres e de Águas Doces e Salobras Portugal Continental. Ideiagrafix, Lisbon, Portugal.

Anderson, M.T.; Kiesecker, J.M.; Chivers, D.P. \& Blaustein, A.R. (2001). The direct and indirect effects of temperature on a predator -prey relationship. Canadian Journal of Zoology 79: 1834-1841.

Bacon, J.P.; Gray, J.A \& Kitson, L. (2006). Status and conservation of the reptiles and amphibians of the Bermuda islands. Applied Herpetology 3: 323-344.

Ballengée, B. \& Sessions, S.K. (2009). Explanation for missing limbs in deformed amphibians. Journal of Experimental Zoology B 312: 770-779.

Baptista, N.; Penado, A. \& Rosa, G.M. (2015). Insights on the Triturus marmoratus predation upon adult newts. Boletín de la Asociación Herpetológica Española 26: 3-5.

Blaustein, A.R. \& Johnson, P.T.J. (2003). The complexity of deformed amphibians. Frontiers in Ecology and the Environment 1: 87-94.

Blaustein, A.R.; Romansic, J.M.; Kiesecker, J.M. \& НАтсн, A.C. (2003). Ultraviolet radiation, toxic chemicals and amphibian population declines. Diversity and Distributions 9: 123-140.

Borkin, L.J. \& Pikulik, M.M. (1986). The occurrence of polymely and polydactyly in natural populations of anurans of the USSR. Amphibia-Reptilia 7: 205-216.

Bosch, J.; Carrascal, L.M.; Durán, L.; Walker, S. \& Fisher, M.C. (2007). Climate change and outbreaks of amphibian chytridiomycosis in a montane area of Central Spain; is there a link? Proceedings of the Royal Society B 274: 253-260.

Bowerman, J.; Johnson, P.T.J. \& Bowerman, T. (2010). Sublethal predators and their injured prey: linking aquatic predators and severe 
limb abnormalities in amphibians. Ecology 91: 242-251

Burkhart, J.G.; Ankley, G.; Bell, H.; CarpenTer, H.; Fort, D.; Gardiner, D.; Gardner, H.; Hale, R.; Helgen, J.C.; Jepson, P.; JohnSon, D.; Lannoo, M.; Lee, D.; Lary, J.; Levey, R.; Magner, J.; Meteyer, C.; Shelby, M.D. \& Lucier, G. (2000). Strategies for assessing the implications of malformed frogs for environmental health. Environmental Health Perspectives 108: 83-90.

Caetano, M.H. (1988). Estudo sobre a Biologia das Populações Portuguesas de Triturus marmoratus (Latreille, 1800) e Triturus boscai (Lataste, 1879). Morfologia, Ecologia, Crescimento e Variabilidade. Ph.D. Dissertation, Universidade de Lisboa, Lisboa, Portugal.

Cisternas, R. (1865). Polymélie dans un Alytes obstetricans Wagl. Revue et Magasin de Zoologie (2) 17: 287-288.

Daveau, S. (1971). La glaciation de la Serra da Estrela. Finisterra 6: 5-40.

Duarte, B. \& CAÇAdor, I. (2012). Particulate metal distribution in Tagus estuary (Portugal) during a flood episode. Marine Pollution Bulletin 64: 2109-2116.

Fernández-Álvarez, F.Á.; Recuero, E.; MarTínEZ-Solano, Í. \& BuCKLEY, D. (2011). First record of bicephaly in Lissotriton boscai (Amphibia, Caudata, Salamandridae). North-Western Journal of Zoology 7: 161-163.

Flyaks, N.L. \& Borkin, L.J. (2004). Morphological abnormalities and heavy metal concentrations in anurans of contaminated areas, eastern Ukraine. Applied Herpetology 1: 229264.

Galán, P. (2011). Anfibios con malformaciones en el Parque Natural das Fragas do Eume (A Coruña, Galicia). Boletín de la Asociación Herpetológica Española 22: 65-67.

García-Muñoz, E.; Jorge, F.; Rato, C. \& Carretero, M.A. (2010). Four types of malformations in a population of Bufo boulengeri (Amphibia, Anura, Bufonidae) from the Jbilet Mountains (Marrakech, Morocco). Her- petology Notes 3: 267-270.

Grasshoff, K. (1976). Methods of Seawater Analysis. Verlag Chimie, New York, USA.

Gurushankara, H.P.; Krishnamurthy, S.V. \& Vasudev, V. (2007). Morphological abnormalities in natural populations of common frogs inhabiting agroecosystems of central Western Ghats. Applied Herpetology 4: 3945 .

Hayden, M.T.; Reeves, M.K.; Holyoak, M.; PerDue, M.; KInG, A.L. \& Tobin, S.C. (2015). Thrice as easy to catch! Copper and temperature modulate predator-prey interactions in larval dragonflies and anurans. Ecosphere 6: 56.

Hebard, W.B. \& Brunson, R.B. (1963). Hind limb anomalies of a western Montana population of the Pacific tree frog, Hyla regilla Baird and Girard. Copeia 1963: 570-572.

Henle, K.; Mester, B.; Lengyel, S. \& Puky, M. (2012). A review of a rare type of anomaly in amphibians, tail duplication and bifurcation, with description of three new cases in European species (Triturus dobrogicus, Triturus carnifex, and Hyla arborea). Journal of Herpetology 46: 451-455.

Héron-Royer, L.-F. (1884). Cas tératologiques observés chez quelques têtards de batraciens anoures et de la possibilité de prolonger méthodiquement l'état larvaire chez les batraciens. Bulletin de la Société Zoologique de France 9: 162-168.

Hill, R.E. \& Lettice, L.A. (2013). Alterations to the remote control of Shh gene expression cause congenital abnormalities. Philosophical Transactions of the Royal Society of London B 368: 20120357.

Hof, C.; Araújo, M.B.; Jetz, W. \& RahbeK, C. (2011). Additive threats from pathogens, climate and land-use change for global amphibian diversity. Nature 480: 516-519.

Hoppe, D.M. (2005). Malformed frogs in Minnesota: History and interspecific differences, In M. Lannoo (ed.) Amphibian Declines: The Conservation Status of United States Species. University of California Press, Berkeley, 
California, USA, pp. 103-108.

Jansen, J. (2002). Guia Geobotânico da Serra da Estrela. Instituto da Conservação da Natureza, Lisbon, Portugal.

Johnson, P.T.J. \& Bowerman, J. (2010). Do predators cause frog deformities? The need for an eco-epidemiological approach. Journal of Experimental Zoology B 314: 515-518.

Johnson, P.T.J. \& McKenzie, V.J. (2008). Effects of environmental change on helminth infections in amphibians: exploring the emergence of Ribeiroia and Echinostoma infections in North America, In B. Fried \& R. Toledo (eds.) The Biology of Echinostomes: From the Molecule to the Community, Springer, New York, USA, pp 249-280.

Johnson, P.T.J.; Lunde, K.B.; Ritchie, E.G. \& Launer, A.E. (1999). The effect of trematode infection on amphibian limb development and survivorships. Science 284: 802-804.

Johnson, P.T.J.; Lunde, K.B.; Ritchie, E.G.; Reaser, J.K. \& Launer, A.E. (2001). Morphological abnormality patterns in a California amphibian community. Herpetologica 57: 336-352.

Johnson, P.T.J.; Sutherland, D.R.; Kinsella, J.M. \& Lunde, K.B. (2004). Review of the trematode genus Ribeiroia (Psilostomidae): Ecology, life history and pathogenesis with special emphasis on the amphibian malformation problem. Advances in Parasitology 57: 191-253.

Johnson, P.T.J.; Chase, J.M.; Dosch, K.L.; Gross, J.; Hartson, R.B.; Gross, J.A.; LaRSon, D.J.; Sutherland, D.R. \& Carpenter, S.R. (2007). Aquatic eutrophication promotes pathogenic infection in amphibians. Proceedings of the National Academy of Sciences 104: 15781-15786.

Johnson, P.T.; Reeves, M.K.; Krest, S.K. \& Pinkney, A.E. (2010). A decade of deformities: Advances in our understanding of amphibian malformations and their implications, In D.W. Sparling, G. Linder, C.A. Bishop \& S.K. Krest (eds.) Ecotoxicology of Amphibians and Reptiles, $2^{\text {nd }} \mathrm{ed}$. SETAC Press,
Pensacola, Florida, USA, pp. 511-536.

Kiesecker, J.M. (2002). Synergism between trematode infection and pesticide exposure: a link to amphibian limb deformities in nature? Proceedings of the National Academy of Sciences 99: 9900-9904.

Kiesecker, J.M.; Blaustein, A.R. \& Belden, L.K. (2001). Complex causes of amphibian population declines. Nature 410: 681-684.

Kosyreva, R.J. (1971). Water analysis, In N.I. Kozhin (ed.) Spravochnik Rybovoda po Iskusstvennomu Razvedeniyu Promyslovykh $r y b$, Pishchevaya Promyshlennost, Moscow, Russia, pp. 5-19.

LADA, G.A. (1999). Polydactyly in anurans in the Tambov region (Russia). Russian Journal of Herpetology 6: 104-106

Lannoo, M. (2008). Malformed Frogs: The Collapse of Aquatic Ecosystems. University of California Press, Berkeley, California, USA.

LANnoo, M.J. (2009). Amphibian malformations, In H. Heatwole \& J.W. Wilkinson (eds.) Amphibian Biology Volume 8: Amphibian Decline: Diseases, Parasites, Maladies and Pollution. Surrey Beatty and Sons, Chipping Norton, Australia, pp. 3089-3111.

Lannoo, M.J.; Sutherland, D.R.; Jones, P.; Rosenberry, D.; Klaver, R.W.; Hoppe, D.M.; Johnson, P.T.J.; Lunde, K.B.; Facemire, C. \& Kapfer, J.M. (2003). Multiple causes for the malformed frog phenomenon, In G.L. Linder, S. Krest, D. Sparling \& E.E. Little (eds.) Multiple Stressor Effects in Relation to Declining Amphibian Populations. American Society for Testing Materials, West Conshohocken, Pennsylvania, USA, pp. 233-262.

Lawson, T.B. (1995). Fundamentals of Aquacultural Engineering. Springer, New York, USA.

Lunde, K.B. \& Johnson, P.T.J. (2012). A practical guide for the study of malformed amphibians and their causes. Journal of Herpetology 46: 429-441.

Manouvrier-Hanu, S.; Holder-Espinasse, M. \& LyonNET, S. (1999). Genetics of limb anomalies in humans. Trends in Genetics 15: 409417. 
Mora C.; Vieira G.T. \& Alcoforado M.J. (2001). Daily minimum air temperatures in the Serra da Estrela, Portugal. Finisterra 36: 49-60.

Ouellet, M. (2000). Amphibian deformities: current state of knowledge, In D.W. Sparling, G. Linder \& C.A. Bishop (eds.) Ecotoxicology of Amphibians and Reptiles. SETAC Press, Pensacola, Florida, USA, pp. 617-661.

Ouellet, M.; Bonin, J.; Rodrigue, J.; DesGranges, J.-L. \& Lair, S. (1997). Hindlimb deformities (ectromelia, ectrodactyly) in free-living anurans from agricultural habitats. Journal of Wildlife Diseases 33: 95104.

Reeves, M.K.; Dolph, C.L.; Zimmer, H.; TJeerdema, R.S. \& Trust, K.A. (2008). Road proximity increases risk of skeletal abnormalities in wood frogs from National Wildlife Refuges in Alaska. Environmental Health Perspectives 116: 1009-1015.

Reeves, M.K.; Jensen, P.; Dolph, C.L.; Holyoak, M. \& Trust, K.A. (2010). Multiple stressors and the cause of amphibian abnormalities. Ecological Monographs 80: 423-440.

Reeves, M.K.; Perdue, M.; Blakemore, G.D.; Rinella, D.J. \& HolyoaK, M. (2011). Twice as easy to catch? A toxicant and a predator cue cause additive reductions in larval amphibian activity. Ecosphere 2: 72.

Reeves, M.K.; Medley, K.A.; Pinkney, A.E.; Holyoak, M.; Johnson, P.T.J. \& Lannoo, M.J. (2013). Localized hotspots drive continental geography of abnormal amphibians on U.S. wildlife refuges. PLoS One 8: e77467.

Romansic, J.M.; Waggener, A.A.; Bancroft, B.A. \& Blaustein, A.R. (2009). Influence of ultraviolet-B radiation on growth, prevalence of deformities, and susceptibility to predation in Cascades frog (Rana cascadae) larvae. Hydrobiologia 624: 219-233.

Rosa, G.M.; Laurentino, T. \& Madeira, M. (2012). Field observation of foraging behav- ior by a group of adult diving beetles $A g a$ bus (Gaurodytes) bipustulatus preying on an adult Lissotriton boscai. Entomological Science 15: 343-345.

Rosa, G.M.; Anza, I.; Moreira, P.L.; Conde, J.; Martins, F.; Fisher, M.C. \& Bosch, J. (2013). Evidence of chytrid-mediated population declines in common midwife toad in Serra da Estrela, Portugal. Animal Conservation 16: 306-315.

Rothschild, B.M.; Schultze, H.-P. \& PelleGRINI, R. (2012). Herpetological Osteopathology. Annotated Bibliography of Amphibians and Reptiles. Springer, New York, USA.

Sessions, S.K. \& Ruth, S.B. (1990). Explanation for naturally occurring supernumerary limbs in amphibians. Journal of Experimental Zoology 254: 38-47.

Simões, J.M.M. (2005). Ocorrência das espécies Lymnæa (Pseudosuccinea) columella Say, 1817 (Mollusca, Gastropoda, Limneidæ) e Planorbella sp. (Mollusa, Gastropoda, Planorbiidæ) em Portugal. Portugala 25: 26.

Stuart, S.; Chanson, J.S.; Cox, N.A.; Young, B.E.; Rodrigues, A.S.L.; Fishman, D.L. \& WALLER, R.W. (2004). Status and trends of amphibian declines and extinctions worldwide. Science 306: 1783-1786.

Talavera, S.; Aedo, C.; Castroviejo, S.; Romero Zarco, C.; SÁez, L.; SAlgueiro, F.J. \& Velayos, M. (2001). Flora iberica. Plantas Vasculares de la Península Ibérica e Islas Baleares. Vol. VII (I) Leguminosae (partim). Real Jardín Botánico, Madrid, Spain.

Tejedo, M. (2003). El declive de los anfibios. La dificultad de separar las variaciones naturales del cambio global. Munibe 16: S20S43.

Whited, J.L. \& TABin, C.J. (2009). Limb regeneration revisited. Journal of Biology 8: 5 .

Williams, R.N.; Bos, D.H.; GopurenKo, D. \& DeWoody, J.A. (2008). Amphibian malformations and inbreeding. Biology Letters 4: 549-552. 